\section{CÓDIGO DE OBRIGAÇÕES}

\section{Ernesto Martins Vieira}

Professor Catedrático de Direito Comercial da Faculdade de Direito de Goiaz.

Sob o império das Ordenações três vêzes seculares, viveu o Brasil até 1917, quando teve vigência o Código Civil, admirável monumento jurídico, para a época. Para 1850 o Código Comercial representa um trabalho que exalta seus confeccionadores.

Mas o mundo tem vivido com intensidade e a ciência, nestes últimos 50 anos, progrediu assombrosamente, indo ao extremo da produção da energia pela desintegração atômica. Com a transformação da matéria em energia, não se adquire um triunfo com repercussões de ordem puramente material. Um espantoso problema filosófico está pôsto ante a Humanidade, que sempre se calcou em um mundo de matéria em cata de pontos fixos na imobilidade. A nova civilização, que se anuncia através guerras cruentas e atrocíssimas para que dos escombros do passado se possa estruturar o futuro; a nova civilização terá apoio na energia, onde estará o ponto fixo das novas construções materiais e conceptuais. No setor do pensamento, ver-se-á que a verdade não se estratifica num ponto inerte do absoluto, mas se constitui de uma trajetória, sempre em busca de novos avanços, num transformismo constante, numa evolução sem descontinuar.

A lei ascende e se transmuda e, amanhã, a presente justiça, formal e coercitiva, passará a ser violação e agressão, porque novos e mais profundos equilíbrios serão descobertos à humanidade. A própria guerra, suprema manifestação da brutalidade dos povos atualmente, se diz justa e justa realmente é pelo único motivo de se constituir em esfôrço por alcançar maior perfeição, dentro da qual será possível sua radical supressão.

A evolução não cessa, não tem cansar, e, se parece amortecida e inerte, é porque está cristalizando fôrças para ganhar em intensidade o que perdeu em tempo. Sua ação recai nas coletividades e nos indivíduos, suprimindo sempre a violência e o egoísmo, por serem expressões emperradoras do evolver crescente. Se da violência e do egoísmo, o indivíduo aufere vantagens, todavia sofre, si- multâneamente, os seus danos, e êsses deixam funda impressão nos instintos, criando uma reação natural em prol da eliminação das causas de seus males. Eis surgente a idéia da utilidade coletiva com assento na supressão do abuso individual e, com ela, a progressiva, constante e reiterada eliminação dos ímpetos egoísticos. Esta a razão pela qual o direito se institui, se modifica e sempre adquire novas formas, impregnando-se cada vez mais de crescente dose de ética, dentro da qual culpa é retrocesso e virtude avanço.

A evolução persiste sempre, teimosa e renitente, e aí está a razão pela qual o Direito é uma formação contínua, sendo a codificação mera tentativa. Agora; mais que nunca, desponta a época em que o progresso jurídico se acentuará, com a filosofia mais espiritual, decorrente da nova civilização que dá à luz a Humanidade nestes estertores dolorosos de uma espetacular delivrance.

Não sabemos, nem é possível adivinhar-se qual o regulamento jurídico das porvindouras sociedades. Adotemos, por isso, o que de melhor houver para a atualidade, sem trancar as portas à penetração de idéias reformadoras. O que não é justo, o que é desarrazoado, é que mantenhamos um Código Comercial de 100 anos; sua reforma se impõe.

Contudo, por quê conservar uma compilação só atinente a uma classe de indivíduos, quando em outro departamento jurídico há normas similares? Por quê não fundir um no outro, formando um só todo onde os princípios gerais e comuns apareçam enunciados uma só vez e onde as normas especialíssimas para a classe dos comerciantes possam existir, sem prejuízo do todo ?

A similitude das normas que presidem as transações mercantis e aquelas que dominam as civis, é irrecusável. Onde se impuserem disposiçõs especiais, inscrevam-se elas em capítulos especiais. Facilita-se assim o estudo do direito privado e sua aplicação sem maiores perigos de orientações diferentes tomadas pelo Poder Judiciário.

Ademais não há razões para que seja a hipoteca regulada exclusivamente por leis civis, quando é aquêle instituto muito empregado entre comerciantes e para fins sòmente mercantis. Também não procede que as letras de câmbio e as notas promissórias se submetam sòmente às leis comerciais, se hoje em dia são empregadas pelos banqueiros, largamente pelos não comerciantes, e não só excepcionalmente por êstes.

Já não queremos insistir na ampliação das concordatas para os que não sejam comerciantes, embora vejamos nisso uma imposição da realidade dos fatos, a que Inglez de Sousa deu tanto relêvo; e não queremos insistir porque o assunto, perante a presente tese, é mero detalhe. 
A supressão de repetição dos mesmos princípios, em dois Códigos, é uma decorrência das condições modernas, e assume proporções de imperativo ante a necessidade proclamada e reconhecida de reforma nos dois Códigos, Civil e Comercial.

Que se faça a reforma geral por etapas, parceladamente, por via de modificações nos "livros" do Código Civil, parceladamente, por a precisa autonomia, como também estabelecendo codificações especiais para as matérias que comportarem tais especializações, como as sociedades, os transportes.

A Parte Geral do Código Civil se constitui de normas gerais mais atinentes ao departamento das Obrigações, com reflexos excepcionais nas demais partes do Código Civil e, portanto, justo será que suas normas se enquadrem sòmente no Código das Obrigacões aliás atendendo-se à orientação germânica cójigo das Obrigações, nunca foi superado. As demais disposições da Parte Geral, que tenham referência a outros departamentos do Direito Civil, que sejam incluídas nos Códigos especiais da Propriedade e da Família sejam incluídas nos

Pugnamos, pois, pela supressão dos Códigos Civil e Comercial, substituindo-os por vários Códigos que enfeixem os princípios reguladores da Propriedade, da Famúlia e Sucessão, das Sociedades, das Obrigações, dos Transportes e das Falências e Concordatas, E somos de parecer que se deva atingir a meta final, paulatinamente, com as sucessivas vigências dos diferentes códigos novos, reformadores ou consolidadores da legislação atual.

Uma primeira tentativa se fêz: - o projeto de Código de Obrigações, organizado por Orozimbo Nonato, Filadelfo de Azevedo e Hahnemann Guimarães, em 1941, e basta a citação de tais nomes, para que nos ponhamos em posição de homenagem, não menor que aquela, que estávamos habituados a prestar ao primeiro, desde quando, como Professor ou Desembargador, transformava Belo Horizonte em um templo de ensinamentos.

Não é possível que se perca tanto esfôrço, tanta inteligência, tamanha concentração de espírito. Preciso é que se conclua a ebra alargando-a aos novos Códigos. Os iniciadores aí conclua a obra, certamente com boa vontade. Outros jurisconsultos com aguçado acume de sabedoria não faltarão e, neste Congresso, muitos estão presentes.

A mutação do cenário para fins justos não viria, com presteza, através a unificação de todo o Direito Privado e sim por via da Direito de Obrigações.

O Direito Civil sempre foi um direito de autoridade (Laurent, De la Fusion du Dr. Civ. et du D. Com. pag. 21) emanado do poder público e impôsto aos jurisdicionados. O Direito Comercial, desde seu início, foi rumando para um direito de convenção, em que a vontade dos jurisdicionados era a grande lei e a inesgotável fonte das relações jurídicas. Seu campo de ação originàriamente restrito aos comerciantes, uns com os outros, ampliou-se, fortemente invadindo o território e as pessoas que sòmente o Direito Civil regia. Essa usurpação não cessou, mas, por uma natural reação, o Direito Civil recebeu os influxos do Direito Comercial e a vontade das partes passou a ser também ali o farto manancial das obrigações entre não comerciantes. Já na legislação aragonesa devia o julgador "stare semper et judicare ad chartam et secundum quod in ea continetur" ( $\mathrm{J}$. Costa, El problema de Derecto, pag. 47) só se esquivando dêste norteamento quando houvesse o impossível materialmente ou quando contrariasse o direito natural. Hoje em dia êsse mesmo princípio domina: - a vontade dos pactuantes é a grande criadora das obrigações e a lei só funciona quando a vontade omitiu qualquer manifestação a respeito. A vontade está sobreposta à lei, que pode mesmo, para casos concretos, ser derrogada por aquela (Dalloz,, Repert. \$ 672)

Assim, quer nas obrigações civis quer no Direito Comercial, é a vontade das partes senão a única, pelo menos quase a única geradora da grande maioria dos vínculos jurídicos que jungem pessoas para certas prestações.

Se a causa é a mesma, produzindo o mesmo efeito, por quê dividir as obrigações em naturezas diversas, em atenção às pessoas que nelas possam figurar? A obrigação, civil ou comercial, constitui um instituto jurídico único; suas origens não são diversas; possui a mesma anatomia; não se diferencia por suas funções; sua patologia, conquanto protéica, é a mesma para uma e outra espécie. Por quê diversificar a terapêutica? O exercício de profissões especializadas por seus agentes não é razão suficiente nem convincente.

Ademais, os princípios reguladores das Obrigações reunidos num só todo trazem a possibilidade, a facilidade de serem modificados e adaptados a novas exigências impostas. pelo evoluir.

Há úma ânsia incontível nos povos para ministrar à coletividade poderes de coordenação e harmonia, tais que orientem as atividades individuais, sem hipertrofias, rivalidades ou competições, em que sempre os mais fracos são esmagados, anuladas capacidades em francas dispersões. As fôrças econômicas estão recebendo novos influxos; diferente orientação as impulsiona. $\mathrm{E}$, se se atentar para o departamento do Direito Privado, na parte que prescreve as obrigações, se verá que é êle que mais de perto sofrerá a influência renovadora dêstes princípios, porque constitui, na realidade, a principal trama fundamental de tôda relação jurídica. Seu conceito terá de modificar-se, a fim de adaptar-se à colaboração dos indivíduos, fugindo à luta que decorre inevitável do materialista do ut des, do ut facias, facio ut facias. 
Na previsão muito antecipada de Stammler a obrigação passará a ser "um vínculo jurídico para a cooperação social". A autonomia da vontade nos contratos terá de ceder em parte, em face da função social dêstes.

A doutrina das Obrigações, decorrente da organização social, submete-se às imposições desta, mas também não se conserva formas rígidas, porque reage e evolve com a evolução e maturação do homem. Se é uma conseqüência da organização social, tem também reações sôbre si mesma, e se transmuda em causa da modificação daquela organização, porque inegàvelmente esta nada mais é que o revestimento da coletividade, impôsto pelo estado psíquico dos indivíduos. Cada passo avante que o psiquismo der, nova organização será reclamada, porque em grande modificação estarão as relações individuais e, conseqüentemente, com outros delineamentos se apresentará a doutrina das obrigações.

Nesse entrosamento ininterrupto vivem o homem e a sociedade e se forma e se transforma o Direito de Obrigações. A interdepêndencia é inegável.

A doutrina das Obrigações tem tal e tão palpável eficácia na coesão do organismo social que "é ela que paira mais próxima do ideal de justiça, centro de gravidade das leis e instituições" (Savigny, Oblig. \$ 4 ).

Não é, portanto, justo que, numa fase de renovação, como a em que vivemos, se conserve em dicotomia tão eloqüente fator social, constituindo dois corpos, como se fôssem estranhos ou divergentes. A unificação se impõe pelo imperativo das condições sociais modernas e das que se avizinham.

Não importa que o Projeto contenha falhas ou alguns excessos, não importa que se percebam nêle alguns defeitos. E um projeto, sujeito, portanto, a acréscimos, cortes e remates. $\mathrm{E}$ mínimas rão as adaptações, porque muitas são as suas excelências. Admirável é êle, não simplesmente por conter uniformidade de princípios, mas também porque corajosamente adota princípios, que a doutrina reclama e as leis teimam em não consignar. Assim a inexperiência e o estado de necessidade do pactuante a viciar o consentimento nas declarações de vontade; assim a predestinação dos contratos impressa nesses como latente cláusula resolutiva; assim a ampliação razoável do uso dos poderes pelo procurador; assim a ampliação focalização nos atos jurídicos, não do concurso de vontades coincidentes, mas a declaração da vontade de cada pactuante, proclamando, assim, como fonte de qualquer conseqüência jurídica, uma vontade manifestada, embora unilateralmente.

Em conclusão: - propugnamos pelo aproveitamento e terminaçầo do Código de Obrigações, cujo projeto parcial foi organizado por Orozimbo Nonato, Filadelfo de Azevedo e Hahnemann Guima rães; prosseguindo o trabalho planejado para a organização dos demais Códigos da Propriedade, da Família e Sucessões, das Sociedades, das Falências e Concordatas.

\section{DEBATES EM PLENÁRIO}

O SR. PRESIDENTE - Júlio César Bonazzola - Passa-se à discussão de novo trabalho: "Necessidade da unidade de critério na sub-rogação legal, em face do Direito Civil e do Direito Comercial". Esta tese é da autoria do professor Ernesto Martins Vieira, catedrático da Faculdade de Goiás, sendo seu relator o professor Bruno de Mendonça Lima, a quem concedo a palavra.

O SR. BRUNO DE MENDONÇA LIMA - (Lê o Relatório e parecer e, finalizando) Êste parecer foi discutido e aprovado, e recomendada a sua aprovação ao plenário, pela Comissão de Direito Comercial. (Palmas.)

O SR. PRESIDENTE - Submeto à consideração do plenário a tese da eqüivalência da sub-rogação legal do Direito Civil com - Direito Cambial. Como esta tese está fundamentalmente ligada a outra tese do mesmo autor, referente ao regime da Codificação do Direito das Obrigações, creio que poderíamos tratar simultâneamente do mesmo tema. Pediram-me que fizesse um relato sôbre a tese; como porém eu nunca escrevo se não tenho a quem ditar, não o pude fazer. A tese é apresentada pelo mesmo autor, senhor Ernesto Martins Vieira. Eu peço ao senhor Secretário que leia as conclusões da segunda tese.

O SR. SECRETÁRIO - (lendo) Em conclusão: - propugnamos pelo aproveitamento e terminação do Código de Obrigações, cujo projeto parcial foi organizado por Orozimbo Nonato, Filadelfo de Azevedo e Hahnemann Guimarães, prosseguindo o trabalho planejado para a organização dos demais Códigos da Propriedade, da Família e Sucessões, das Sociedades, das Falências e Concordatas.

O SR. PRESIDENTE - Está em discussão a conclusão do parecer sôbre a tese "Critério Único da Sub-rogação".

Não havendo quem queira discuti-la, vou dá-la por aprovada. (Pausa.) Aprovada!

(Foi constatado que sôbre a tese que versa sôbre a "Autonomia do Direito das Obrigações", não havia subido o respectivo parecer. Foi decidido, então, que o assunto fôsse submetido a um estudo mais acurado. A seguir foi encerrada a sessão.) 